\title{
Studies on Sand and Clay Minerals of Kanaginahala Sub-Watershed in Gadag District, Karnataka, India
}

\author{
Madhusudhan* and P. L. Patil
}

Department of Soil Science and Agricultural Chemistry, College of Agriculture, Dharwad University of Agricultural Sciences, Dharwad - 580 005, Karnataka, India

\begin{tabular}{|l|}
\hline Ke y w o r d s \\
$\begin{array}{l}\text { Sub-watershed, clay } \\
\text { minerals, smectite, } \\
\text { vermiculite and } \\
\text { Kaolin }\end{array}$ \\
\hline Article Info \\
\hline $\begin{array}{l}\text { Accepted: } \\
\text { 15 December } 2019 \\
\text { Available Online: } \\
\text { 20January 2020 }\end{array}$ \\
\hline
\end{tabular}

\section{A B S T R A C T}

Mineralogical study was carried using XRD analysis of six representative pedons of two horizones (Ap andBw) developed over granitegneissin Kanaginahala subwatershed to describe the mineralogical composition of sand and clay fractions. The slope of the study area ranged from 1 to 3 per cent with moderate to severe erosion, soil colour was dark grayish brown (2.5 Y 4/2) tovery dark gray (10 YR 3/1), texture was clay in all the pedons. The $\mathrm{pH}$ was neutral to moderately alkaline ( $\mathrm{pH} 7.55$ to 8.32), with ECnonsaline ( 0.15 to $\left.0.54 \mathrm{dSm}^{-1}\right)$ and organic carbon low to high range( 2.82 to $\left.9.02 \mathrm{~g} \mathrm{~kg}^{-1}\right)$. CEC was relatively high in all the pedons, it ranged from

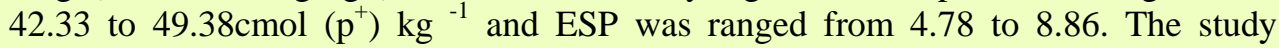
revealed that's mectite was the dominant clay mineral. It varied from 60.3 to 88.7 per cent in Ap horizon and 55.7 to 74.2 per cent inBw horizon, Vermiculite was ranged from 12.6 to 26.8 per cent in surface and 11.2 to 28.4 per cent in Bw horizon, followed by kaolin and quartz. Kaolin and quartz varied from 6.0 to 12.8 per cent and 2.7 to 13.6 per cent, respectively in Ap horizon and 5.2 to 13.4 per cent and 3.0 to 8.9 per cent, respectively in Bw horizon. In most of the pedons, the smectite content increased while kaolin content decreased with soil depth. Among second minerals, smectite dominated over vermiculite and kaolin.

\section{Introduction}

Detailed study was under taken on morphological, physical, chemical and mineralogical composition of soils of Kanaginahala sub-watershed located in Gadagtaluk of Gadag district, Karnataka (Fig. 1). The study area belongs to "Northern dry zone" (Zone 3), which receives the lowest rainfall among all the dry zones of Karnataka.
The availability of moisture is the limiting factor for crop production. The length of growing period (LGP) is 90 to 120 days (Ramamurthy et al., 2009). The Kanaginahala sub-watershed has black soils and the climate is semi-arid with a mean annual average rainfall of $597.5 \mathrm{~mm}$.

Mineralogy is a major factor for determining the sizes, shapes, and surface characteristics of 
the particles in soil and can be a great value for understanding soil properties and its behavior. The data on mineralogical composition of clays is an essential requirement for better understanding of soil formation as well as to the management and improvement practices of crop production. There are other morphological, physical and chemical parameters that can also help us to better understand the exact relationship between soil and parent material, namely; Soil colour, texture, clay percentage, $\mathrm{pH}$, electrical conductivity (EC), organic carbon (OC), exchangeable sodium percentage (ESP) and cation exchange capacity, etc.

\section{Materials and Methods}

For the purpose of understanding genesis and formation of Kanaginahala sub-watershed soils, six representative series were selected for mineralogical study. Morphologically important two soil horizons in each pedon were selected for mineralogical analysis.

The study area represents the "northern dry zone (Zone 3) with a total area of 7163 hectares lies between and $75^{\circ} 40^{\prime}$ and $75^{\circ}$ $45^{\prime}$ East longitudes and $15^{\circ} 24^{\prime}$ and $15^{\circ} 31^{\prime}$ North latitudes. The entire sub-watershed is underlain by peninsular gneiss. This area belongs to semi-arid of hot tropical monsoonic type of climate. The average annual rainfall is $597.5 \mathrm{~mm}$. The maximum temperature during summer is $38.2^{\circ} \mathrm{C}$ and the minimum $14.8^{\circ} \mathrm{C}$ in winter. Mean maximum temperature is $32.9^{\circ} \mathrm{C}$ and mean minimum temperature is $19.2^{\circ} \mathrm{C}$.

Six representative pedons were selected. Soil samples from two selected layers were collected and analyzed for $\mathrm{pH}, \mathrm{EC}, \mathrm{CEC}$, organic carbon (OC) and ESP asper the standard laboratory procedures(Black, 1965, Sarmaet al., 1987). Particlesize separation was carried out by the method suggested by Jackson, (1973)
The clay fractions $(<0.2 \mu \mathrm{m})$ were selected from both the layers, after dispersionusing size segregation procedure of Jackson (1979). Xray diffraction (XRD)analysis of clays of selected soil samples pertaining to representative pedons was carried out. The semi quantification of minerals present in the clay fraction was done by drawing the triangle to the sharp first order peak of representative mineral. The height and breadth of each such triangle was measured to calculate the quantity of that mineral by using the following formulae (Gjems, 1967) and expressed in the percentage.

\section{Results and Discussion}

Soil survey was carried out during March 2016 using IRS P6 LISS-III data, Survey of India toposheet and cadastral map of the villages. After intensive traversing, 21 pedons were studied depending upon soil heterogeneity. Morphological characters like colour, structure, consistency and physicchemical properties like bulk density, water holding capacity, $\mathrm{pH}$, electrical conductivity, organic carbon, cation exchange capacity, etc., were studied for all the profile samples (Table 1). After correlating for the above referred properties of pedons, soils were classified in to six soil series and mapped. Six representative pedons were selected for clay mineralogical study and presented in the paper. Landscape slope ranged from nearly level (0-1\% slope) to gently undulating (1-3 \% slope) and exhibited slight to severe erosion having moderate to well drained conditions. All the pedons were under laid the same parent material i.e. granite-gneiss (Fig. 2).

The $\mathrm{pH}$ (soil reaction) of the soil pedons ranged from neutral to strongly alkaline(7.55 to 8.32 ) in nature. The relatively higher $\mathrm{pH}$ in soils might also be attributed to the accumulation of calcium carbonate in the solum 
The electrical conductivity in the soil was ranged from 0.15 to $0.54 \mathrm{dSm}^{-1}$ indicating non-saline nature of soils. The organic carbon (OC) content ranged from low to high(2.82 to $9.02 \mathrm{~g} \mathrm{~kg}^{-1}$ ), the OC content in watershed was high in the surface and low in sub surface, this was ascribed to the addition of farmyard manure, crop residues and manures to surface horizon than that of sub-surface horizons. The lower contents of organic carbon apparently resulted because of high temperature which might have induced its rapid oxidation (Nagendra and Patil, 2015)

The cation exchange capacity ranged from 42.53 to $49.38 \mathrm{cmol}\left(\mathrm{p}^{+}\right) \mathrm{kg}^{-1}$, the magnitudes of CEC were indicative of presence of mixed type of clay minerals in the pedons. Variation in clay type and content, organic matter and presence of free iron oxides were responsible for variation in CEC in different pedons at varying physiographic positions.

The exchangeable sodium percentage (ESP) ranged from 4.78 to 8.86 . A measure of relative amounts of exchangeable sodium in comparison with the total cations in the soil are dependent on factors such as type of minerals, concentration of electrolytes and status of soluble cations.

\section{Sand mineralogy}

All pedons of Kanaginahala sub-watershed were dominantly developed from granite gneiss. Under such circumstances, the mineralogy of sand fraction is unlikely to vary much. Therefore, only one random sample of fine sand fraction $(<50 \mu \mathrm{m})$ was $\mathrm{X}$ - rayed. The $\mathrm{XRD}$ of the sand fraction is presented in Fig 3.

The sand fraction was dominant in quartz (peaks at $0.423 \mathrm{~nm}, 0.33 \mathrm{~nm}, 0.328 \mathrm{~nm}$ and $0.181 \mathrm{~nm})$. Other minerals present in the sand fractions included feldspar (0.318 to 0.324 $\mathrm{nm})$, olivines $(0.252 \mathrm{~nm})$, biotite mica $(0.167$ $\mathrm{nm})$, pyroxenes $(0.289 \mathrm{~nm})$, ferrihydrides $(0.198 \mathrm{~nm})$ and goethite $(0.245 \mathrm{~nm})$.

\section{Clay mineralogy}

The clay fractions were separated from six soil pedons(MVD, MGR, NGT, VKP NPT and HGK series), clay samples $(<2 \mu$ msize) after dispersion using size segregation procedure of Jackson (1979). X-ray diffraction (XRD) analysis of clays of selected soil pertaining to representative pedons was carried out (Fig. 4 to 13$)$.

The XRD pattern of Mg-saturated clay sample indicated dominant peaks at $1.5 \mathrm{~nm}$ and small peaks at $0.71,1.0$ and $0.32 \mathrm{~nm}$. The $1.5 \mathrm{~nm}$ peak on ethylene glycolation expanded to 1.75 $\mathrm{nm}$ indicating the presence of smectite. The smectite peak shifted to $1.2 \mathrm{~nm}$ on $\mathrm{K}$ saturation at $25{ }^{\circ} \mathrm{C}$ and collapsed gradually to $1.0 \mathrm{~nm}$ when heated progressively from 110 to $550^{\circ} \mathrm{C}$. The $1.4 \mathrm{~nm}$ peak observed with $\mathrm{Mg}-$ ethylene glycolation shifted to $1.2 \mathrm{~nm}$ region on K-saturation at $25{ }^{\circ} \mathrm{C}$ and collapsed gradually to $1.0 \mathrm{~nm}$ when heated progressively from $110{ }^{\circ} \mathrm{C}$ to $550{ }^{\circ} \mathrm{C}$. This behavior indicated the presence of vermiculite mineral. The presence of $0.70 \mathrm{~nm}$ first order peak and $0.35 \mathrm{~nm}$ second order peak, its persistence during K-saturation and heating up to $300{ }^{\circ} \mathrm{C}$ and its disappearance at $550{ }^{\circ} \mathrm{C}$ indicated the presence of interstratified kaolin mineral. The persistence of $0.42 \mathrm{~nm}$ peak under different heat treatments indicated the presence of quartz. Thus, in the Ap horizon of MGR series, smectite> kaolin, vermiculite and quartz were identified as secondary and primary minerals, respectively.

In clay fractions of all pedons, smectite was the dominant clay mineral. It varied from 62.8 to 84.8 per cent. Vermiculite was also present in all the series except MVD and NGT series, it ranged from 13.4 to 17.2 per cent, followed by kaolin and quartz. Kaolin and quartz varied 
from 6.0 to 12.8 per cent and 2.7 to 9.6 percent, respectively.

In all the pedonssmectite content was relatively more when compared to other minerals. The smectite content increased with depth. It was quite unlikely that such a high amount of smectite in these soils could be due to low rainfall of semi-arid conditions (Bhattacharyya et al., 1993). Smectite was also formed possibly from plagioclase during earlier geologic period and is an ephemeral in humid environment. However, its retention is possible because of climate change from humid to semi-arid during PliocenePleistocene transition period (Pal et al., 1989).

The weathering of primary minerals contributes very little to the formation of smectites in the present semi-arid climate (Srivastavaet al., 2002; Nimkar, 2004). The smectite must have been formed in an earlier humid climate and its crystallinity was preserved in non-leaching environment of the dry climate that followed. The higher kaolin content in surface soil as compared to subsurface indicated that the weathering of surface soil clay was higher than subsurface soil clay, which indicated the probability of insitu soil formation (Deb and Sahu, 2010).

The formation of high quantities of smectite and kaolin is not possible in the present semiarid environment. But, its presence in the present climate indicated that these soils were formed in the humid climate of the past.

Since, the smectite is not stable under humid climate, it transformed to kaolin through smectite-kaolinite interstratified mineral. Presence of small amount of kaolin in all the pedons confirmed this hypothesis. Small amounts of $\mathrm{Sm} / \mathrm{K}$ indicated that humid climate did not prolong for a long time. In addition to smectite and kaolin, the presence of vermiculite indicated that weathering of biotite to vermiculite stage as induced by tropical humid climate earlier (Jagadeesha, 2002). Along with the secondary minerals, the presence of primary minerals in appreciable amount indicated that weathering has not reached an advanced stage.

\section{Semi-quantitative estimates of clay Minerals}

The semi-quantitative estimates of minerals in clay fractions of the pedons (MVD, MGR, NGT, VKPNPT andHGK series) indicated that the smectite was the dominant clay mineral both in Ap (62.8 to 84.8 \%) and Bw horizons (66.3 to $82.2 \%$ ) and Vermiculite was ranged from 13.4 and 16.6 per cent in Ap and 11.2 t0 17.2 per cent inBw horizons, respectively, followed by the kaolin (6..0 to 12.8 and 5.0 to $10.7 \%$ in $\mathrm{Ap}$ and $\mathrm{Bw}$ horizons, respectively) and quartz (2.7 to 9.6 and 3.2 to $9.2 \%$ in $\mathrm{Ap}$ and $\mathrm{Bw}$ horizons, respectively). In most of pedons, the smectite content increased while kaolin content decreased with soil depth (Table 2).

Based on the semi-quantitative estimates of mineral only quartz was present as primary mineral and smectite, vermiculite, kaolin are secondary minerals present in clay fractions, the relative dominance of primary minerals in different soil series (depth-wise) are presented in Table 3. In case of primary mineral, quartz is the only primary mineral present in both the depths of all the series other primary minerals were in traces. 
Table.1 Morphological, physico-chemical properties of pedons

\begin{tabular}{|c|c|c|c|c|c|c|c|c|c|c|c|c|c|}
\hline Pedons & location & $\begin{array}{c}\text { Slope } \\
(\%)\end{array}$ & Erosion & $\begin{array}{c}\text { Horizo } \\
\text { nes }\end{array}$ & $\begin{array}{c}\text { Depth } \\
(\mathrm{Cm})\end{array}$ & Texture & Colour & $\begin{array}{l}\text { pH } \\
1: 2.5\end{array}$ & $\begin{array}{c}\mathrm{EC}_{1: 2.5} \\
\left(\begin{array}{c}\mathrm{dS} \mathrm{m}^{-} \\
\mathbf{1}^{-}\end{array}\right.\end{array}$ & $\begin{array}{c}\mathrm{OC} \\
\mathrm{g} \mathrm{kg}^{-1}\end{array}$ & ESP & $\begin{array}{l}\text { Clay } \\
(\%)\end{array}$ & $\begin{array}{c}\text { CEC } \\
\operatorname{cmol}_{\left(p^{+}\right)} \\
\operatorname{kg}^{-1}\end{array}$ \\
\hline \multirow[t]{2}{*}{ P1 } & \multirow[t]{2}{*}{ MVD } & \multirow[t]{2}{*}{$1-3$} & \multirow[t]{2}{*}{ Moderate } & AP & $0-19$ & Clay & $10 \mathrm{YR} 3 / 2$ & 8.27 & 0.15 & 6.01 & 8.12 & 58.75 & 44.69 \\
\hline & & & & Bw2 & $41-68$ & Clay & 10 YR 3/1 & 8.32 & 0.24 & 3.90 & 6.78 & 62.81 & 46.62 \\
\hline \multirow[t]{2}{*}{ P2 } & \multirow[t]{2}{*}{ MGR } & \multirow[t]{2}{*}{$1-3$} & \multirow[t]{2}{*}{ Moderate } & Ap & $0-19$ & Clay & 7.5 YR 3/3 & 8.04 & 0.17 & 2.82 & 6.00 & 54.42 & 45.63 \\
\hline & & & & Bw2 & $41-68$ & Clay & $\begin{array}{c}7.5 \mathrm{YR} \\
2.5 / 3\end{array}$ & 7.81 & 0.28 & 4.02 & 4.83 & 60.71 & 44.47 \\
\hline \multirow[t]{2}{*}{ P3 } & \multirow[t]{2}{*}{ NGT } & \multirow[t]{2}{*}{$1-3$} & \multirow[t]{2}{*}{ Moderate } & Ap & $0-22$ & Clay & $2.5 \mathrm{Y} 4 / 1$ & 7.55 & 0.27 & 9.02 & 5.22 & 54.66 & 42.33 \\
\hline & & & & Bss & $62-118$ & Clay & $2.5 \mathrm{Y} 4 / 2$ & 7.70 & 0.28 & 4.75 & 5.41 & 59.23 & 44.76 \\
\hline \multirow[t]{2}{*}{ P4 } & \multirow[t]{2}{*}{ VKP } & \multirow[t]{2}{*}{$1-3$} & \multirow[t]{2}{*}{ Severe } & Ap & $0-13$ & Clay & $10 \mathrm{YR} 4 / 2$ & 8.24 & 0.38 & 6.20 & 4.98 & 55.88 & 47.57 \\
\hline & & & & Bss & $35-67$ & Clay & $10 \mathrm{YR} 4 / 2$ & 8.31 & 0.39 & 4.53 & 5.40 & 61.61 & 49.38 \\
\hline \multirow[t]{2}{*}{ P5 } & \multirow[t]{2}{*}{ NPT } & \multirow[t]{2}{*}{$1-3$} & \multirow[t]{2}{*}{ Moderate } & Ap & $0-11$ & Clay & $10 \mathrm{YR} 4 / 2$ & 7.68 & 0.22 & 6.21 & 4.87 & 45.32 & 46.37 \\
\hline & & & & Bwk & $11-40$ & Clay & 10 YR 3/1 & 7.58 & 0.23 & 3.53 & 4.78 & 44.25 & 48.73 \\
\hline P6 & HGK & $1-3$ & Moderate & Ap & $0-23$ & Clay & $10 \mathrm{YR} 4 / 1$ & 8.21 & 0.54 & 8.82 & 8.86 & 57.02 & 42.53 \\
\hline
\end{tabular}


Fig.1 Location of Kanaginahala sub-watershed in Gadagtaluka, Gadag district

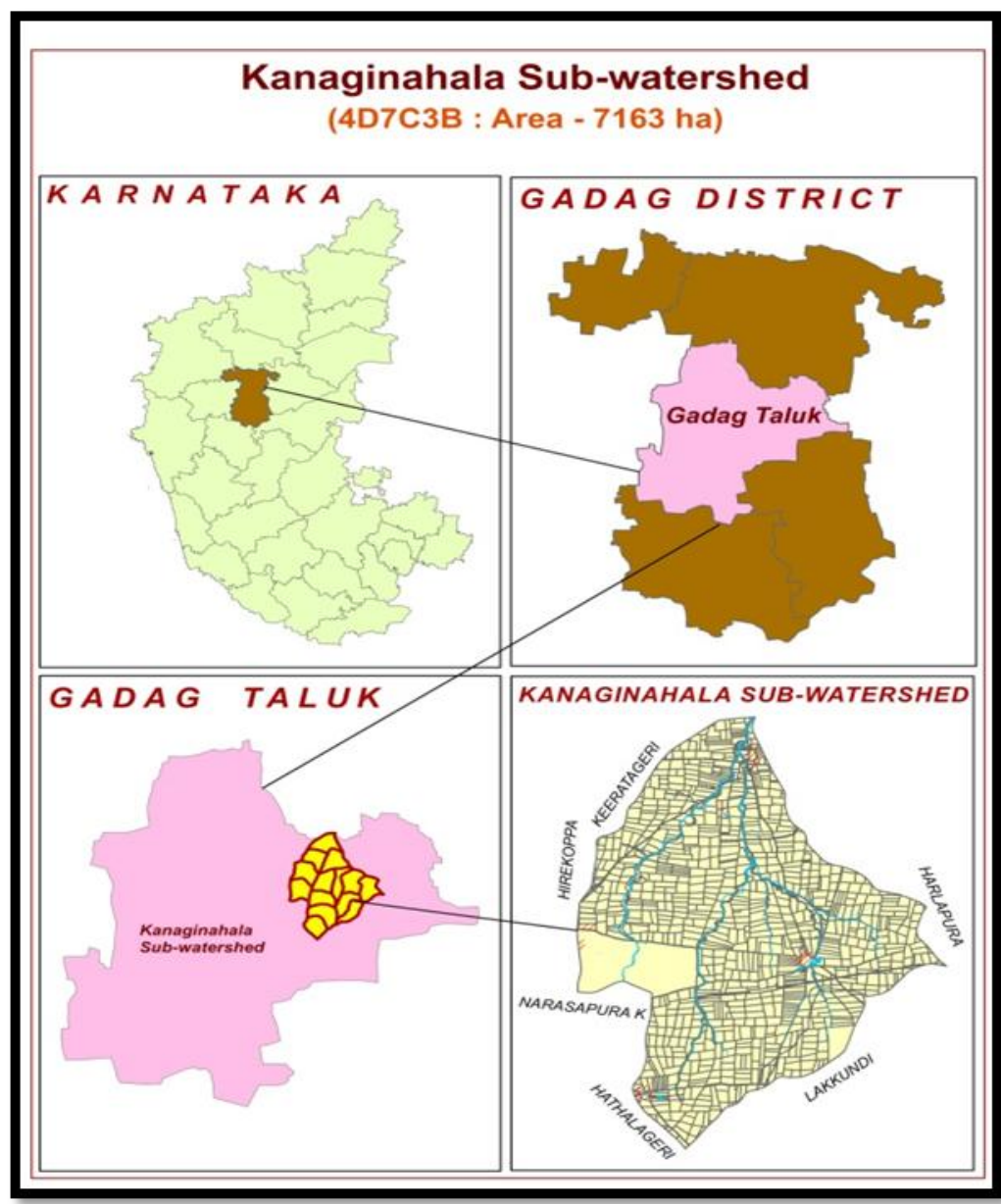

Fig.2 Geology map of Kanaginahala sub-watershed

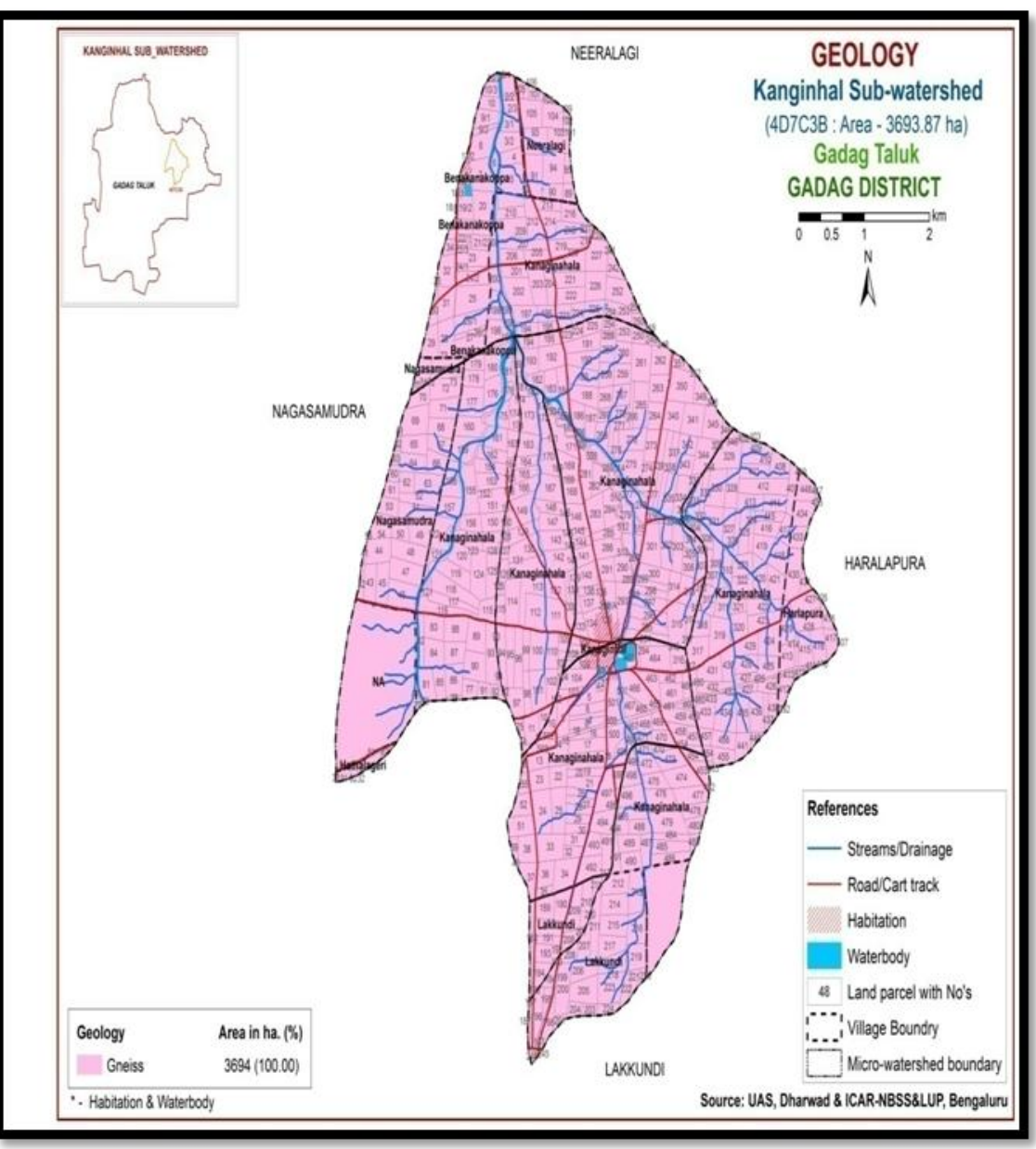


Fig.3 X-ray diffractogram of representative sand fraction

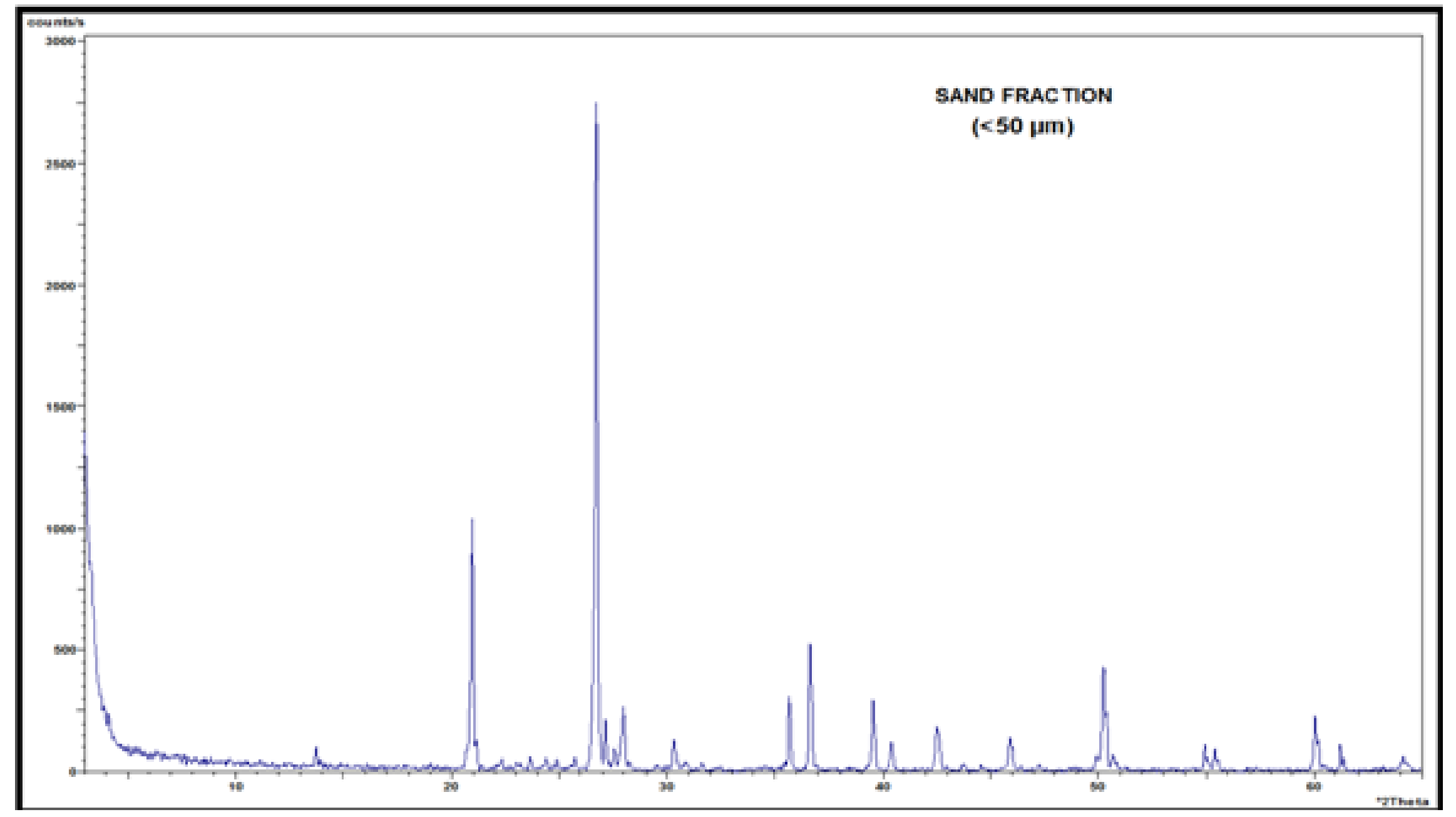


Fig.4 X-ray diffractograms of clay fraction (MVD series, Ap horizon)

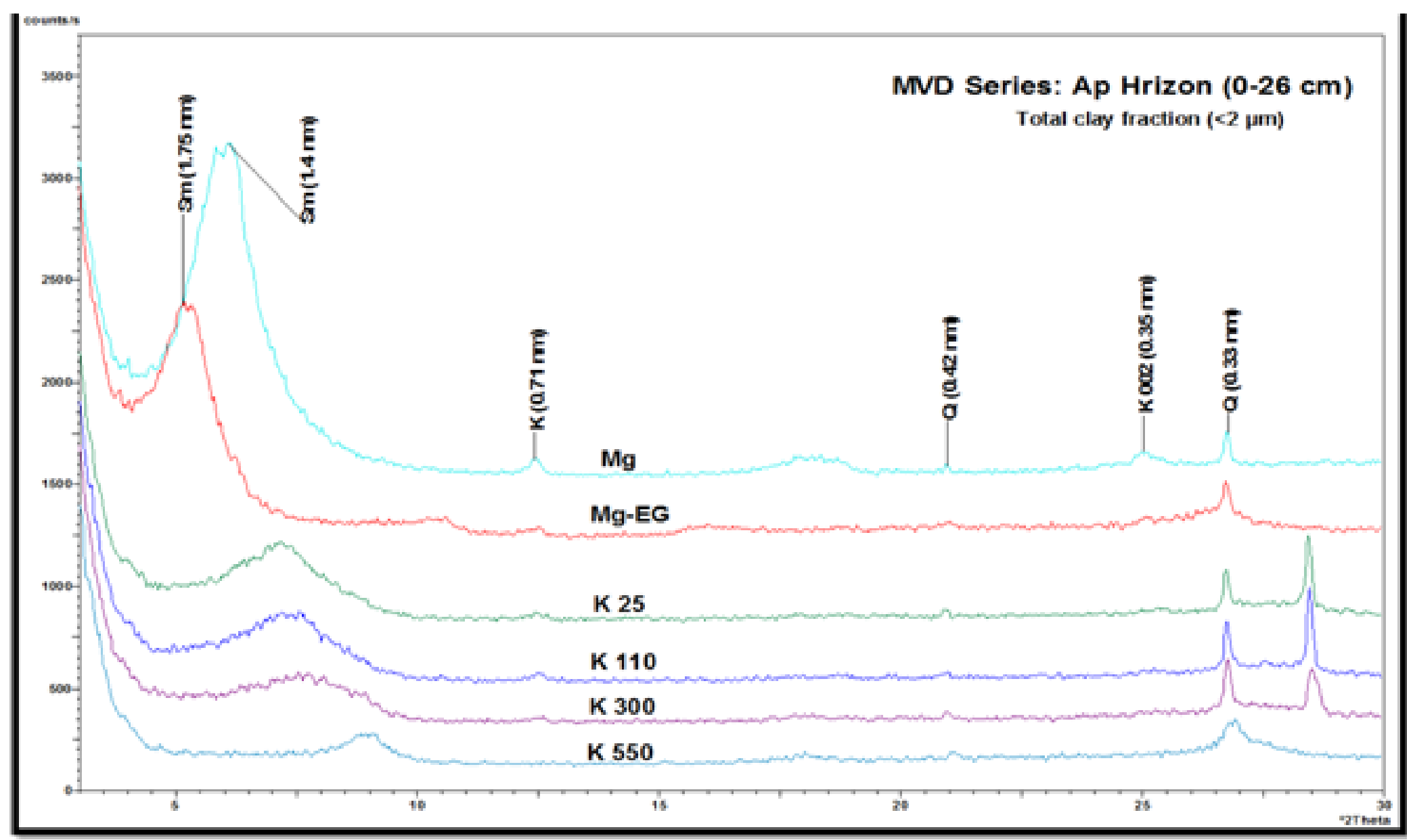

(Sm, smectite; K, kaolin; Q, quartz; Mg, Magnesium saturated; Mg-EG, Mg-saturated and ethylene glycolated; K25, K110, K300, K550-K saturated and heated at $25^{\circ}, 110^{\circ}, 300^{\circ}$ and $550^{\circ} \mathrm{C}$, respectively) 
Fig.5 X-ray diffractograms of clay fraction (MVD series, Bw2 horizon)

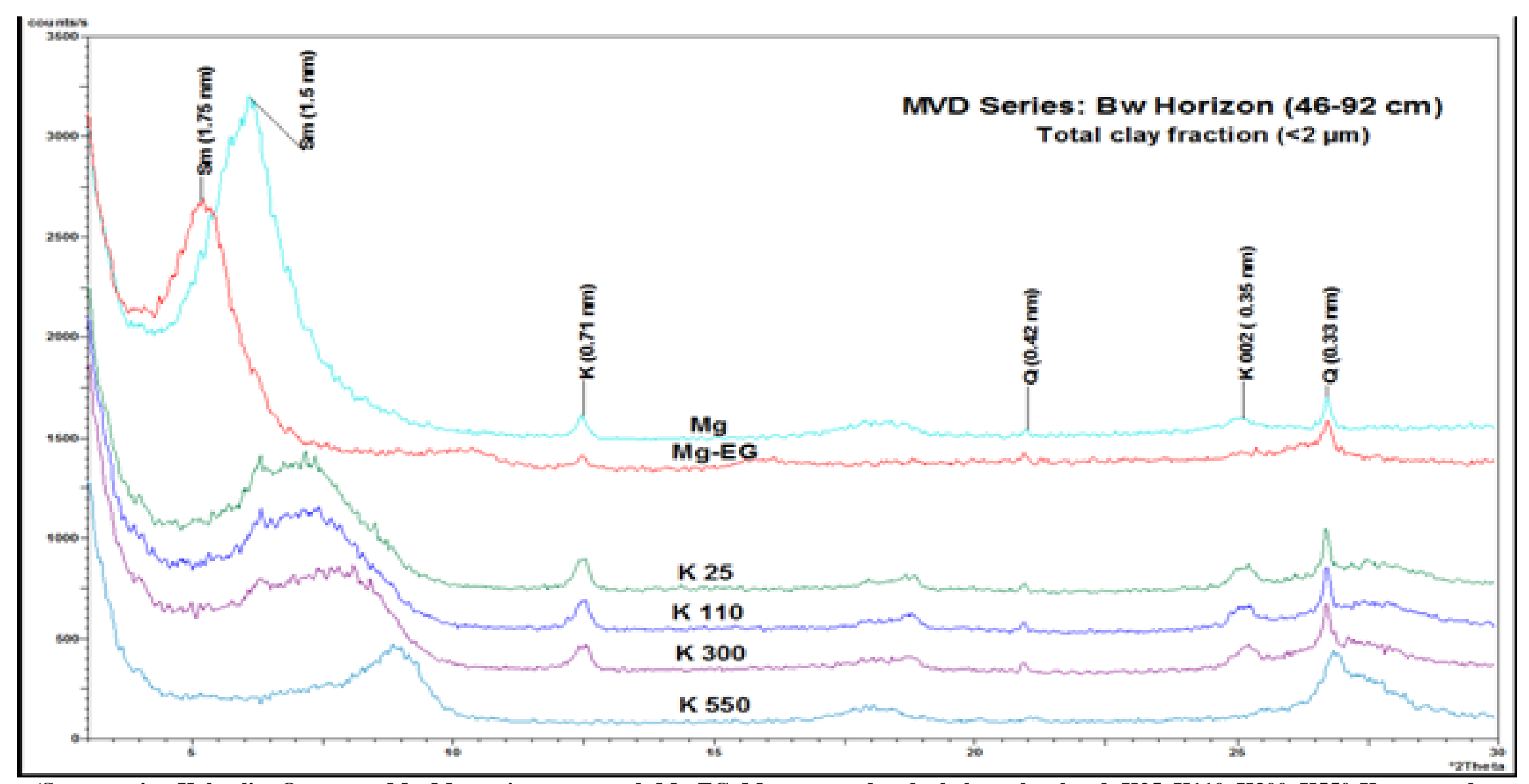

(Sm, smectite; K, kaolin; Q, quartz; Mg, Magnesium saturated; Mg-EG, Mg-saturated and ethylene glycolated; K25, K110, K300, K550-K saturated and heated at $25^{\circ}, 110^{\circ}, 300^{\circ}$ and $550^{\circ} \mathrm{C}$, respectively) 
Fig.6 X-ray diffractograms of clay fraction (MGR series, Ap horizon)

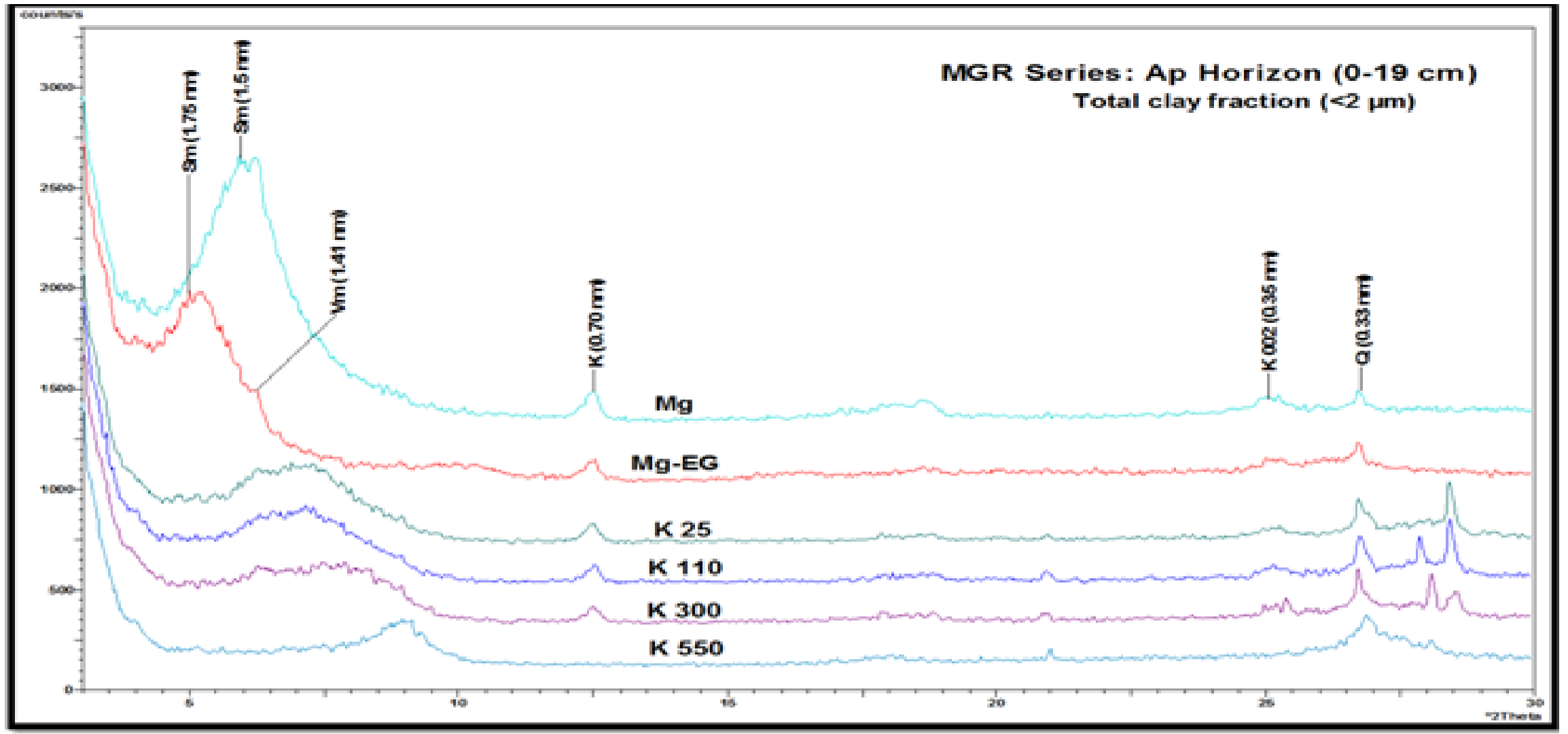

(Sm, smectite; K, kaolin; Q, quartz; Mg, Magnesium saturated; Mg-EG, Mg-saturated and ethylene glycolated; K25, K110, K300, K550-K saturated and heated at $25^{\circ}, 110^{\circ}, 300^{\circ}$ and $550^{\circ} \mathrm{C}$, respectively) 
Fig.7 X-ray diffractograms of clay fraction (MGR series, Bw2 horizon)

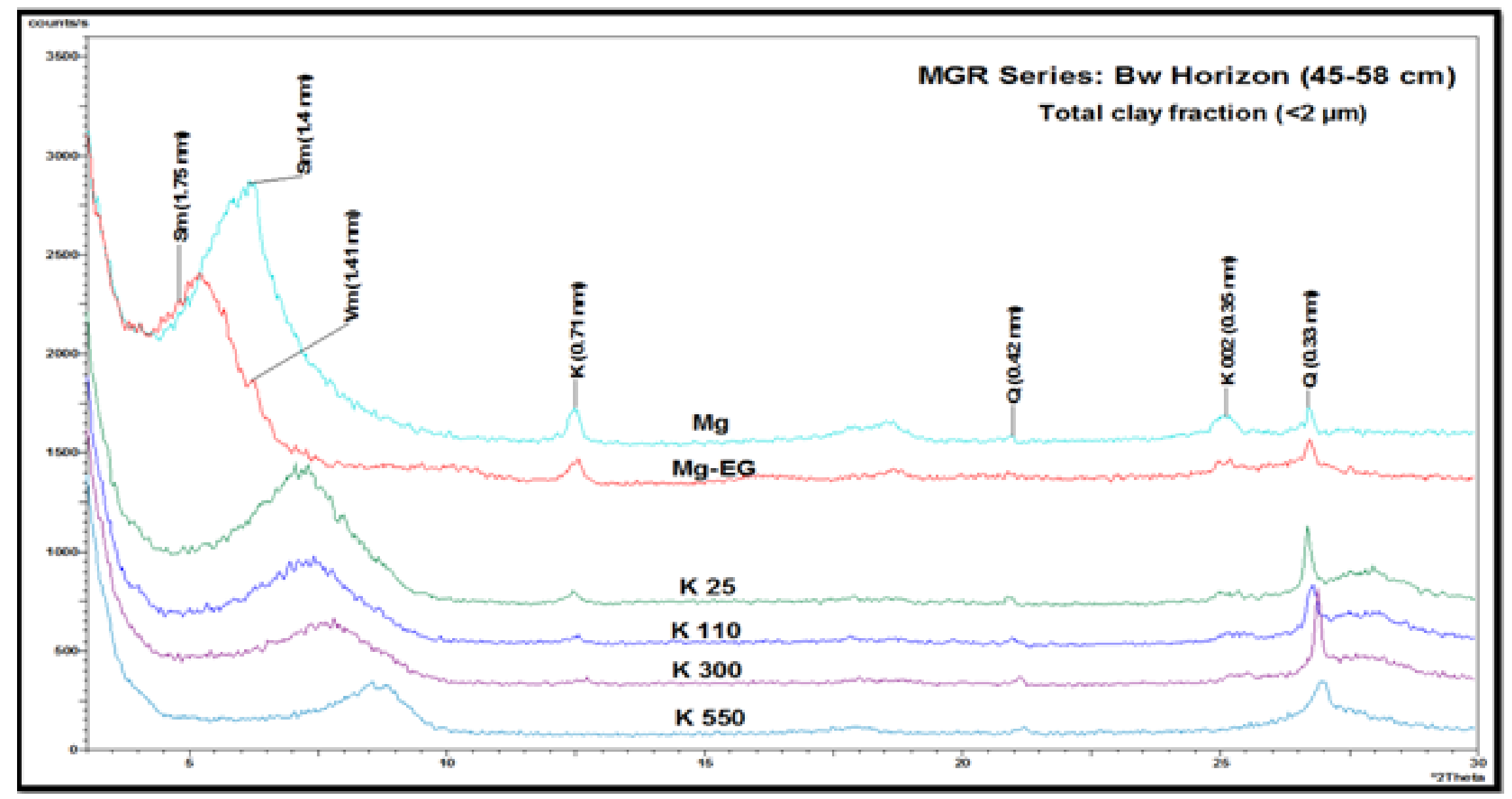

(Sm, smectite; K, kaolin; Q, quartz; Mg, Magnesium saturated; Mg-EG, Mg-saturated and ethylene glycolated; K25, K110, K300, K550-K saturated and heated at $25^{\circ}, 110^{\circ}, 300^{\circ}$ and $550^{\circ} \mathrm{C}$, respectively) 
Fig.8 X-ray diffractograms of clay fraction (NGT series, Ap horizon)

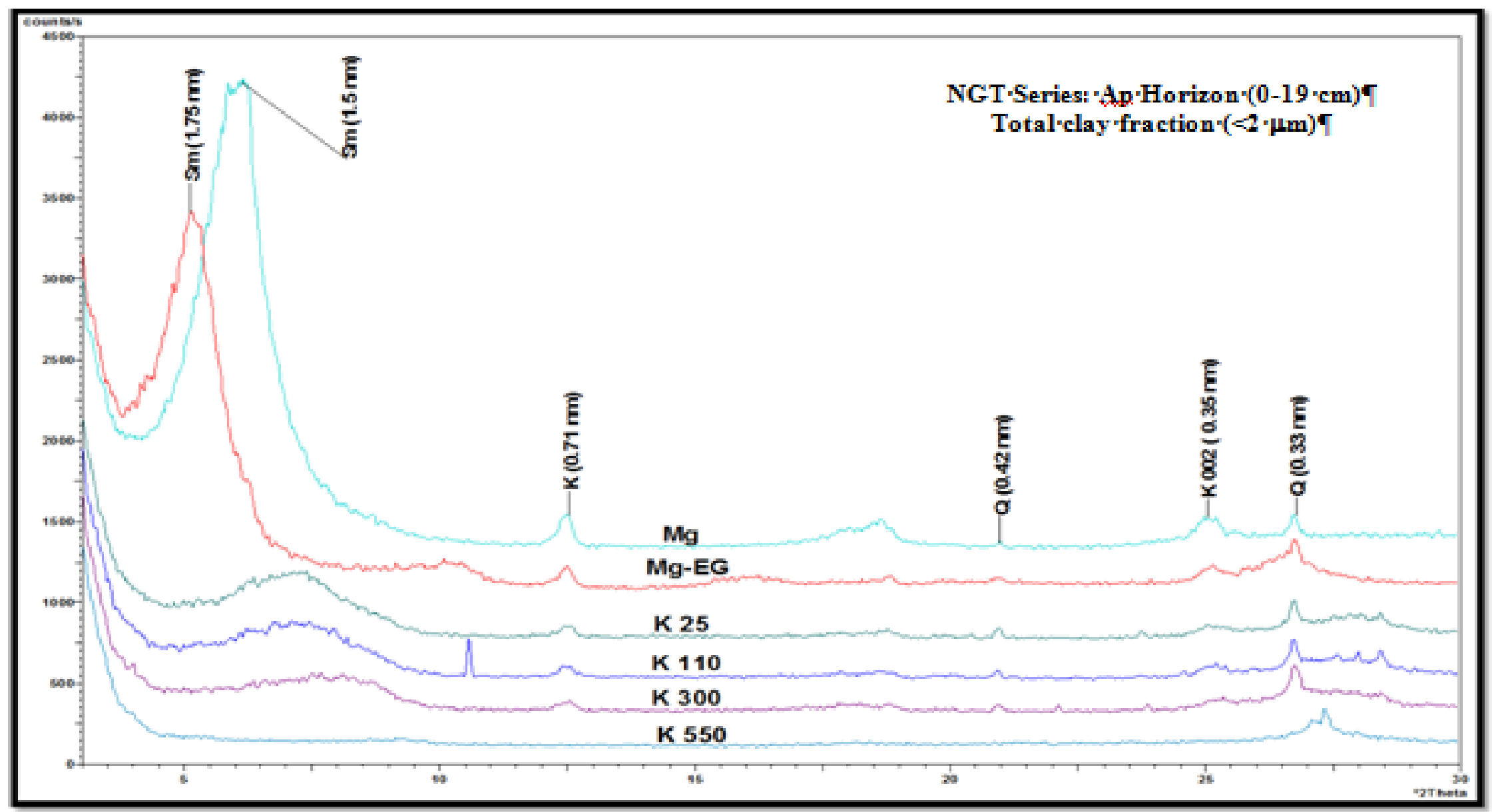

(Sm, smectite; K, kaolin; Q, quartz; Mg, Magnesium saturated; Mg-EG, Mg-saturated and ethylene glycolated; K25, K110, K300, K550-K saturated and heated at $25^{\circ}, 110^{\circ}, 300^{\circ}$ and $550^{\circ} \mathrm{C}$, respectively) 
Fig.9 X-ray diffractograms of clay fraction (NGT series, Bss horizon)

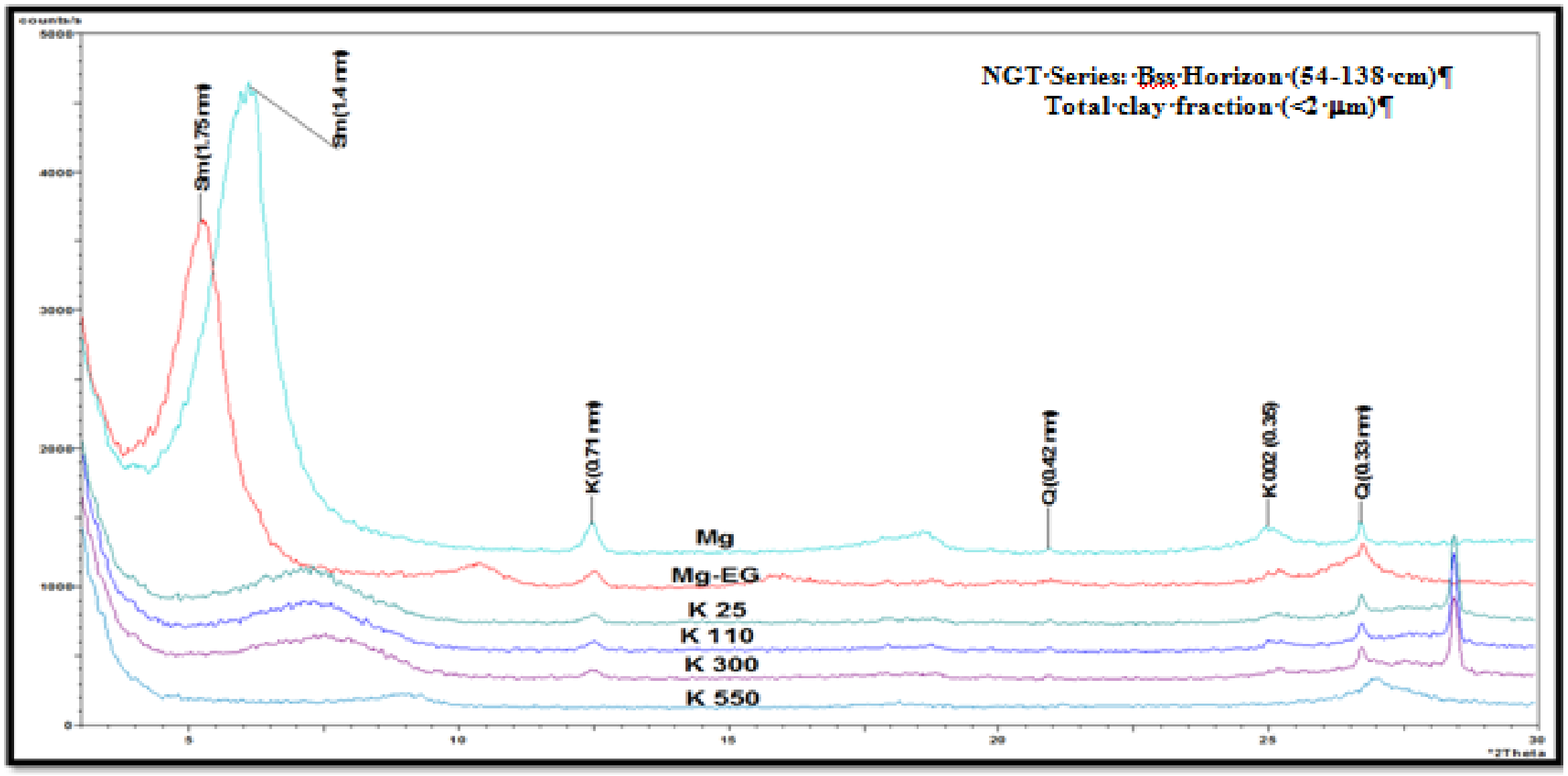

(Sm, smectite; K, kaolin; Q, quartz; Mg, Magnesium saturated; Mg-EG, Mg-saturated and ethylene glycolated; K25, K110, K300, K550-K saturated and heated at $25^{\circ}, 110^{\circ}, 300^{\circ}$ and $550^{\circ} \mathrm{C}$, respectively) 
Fig.10 X-ray diffractograms of clay fraction (VKP series, Ap horizon)

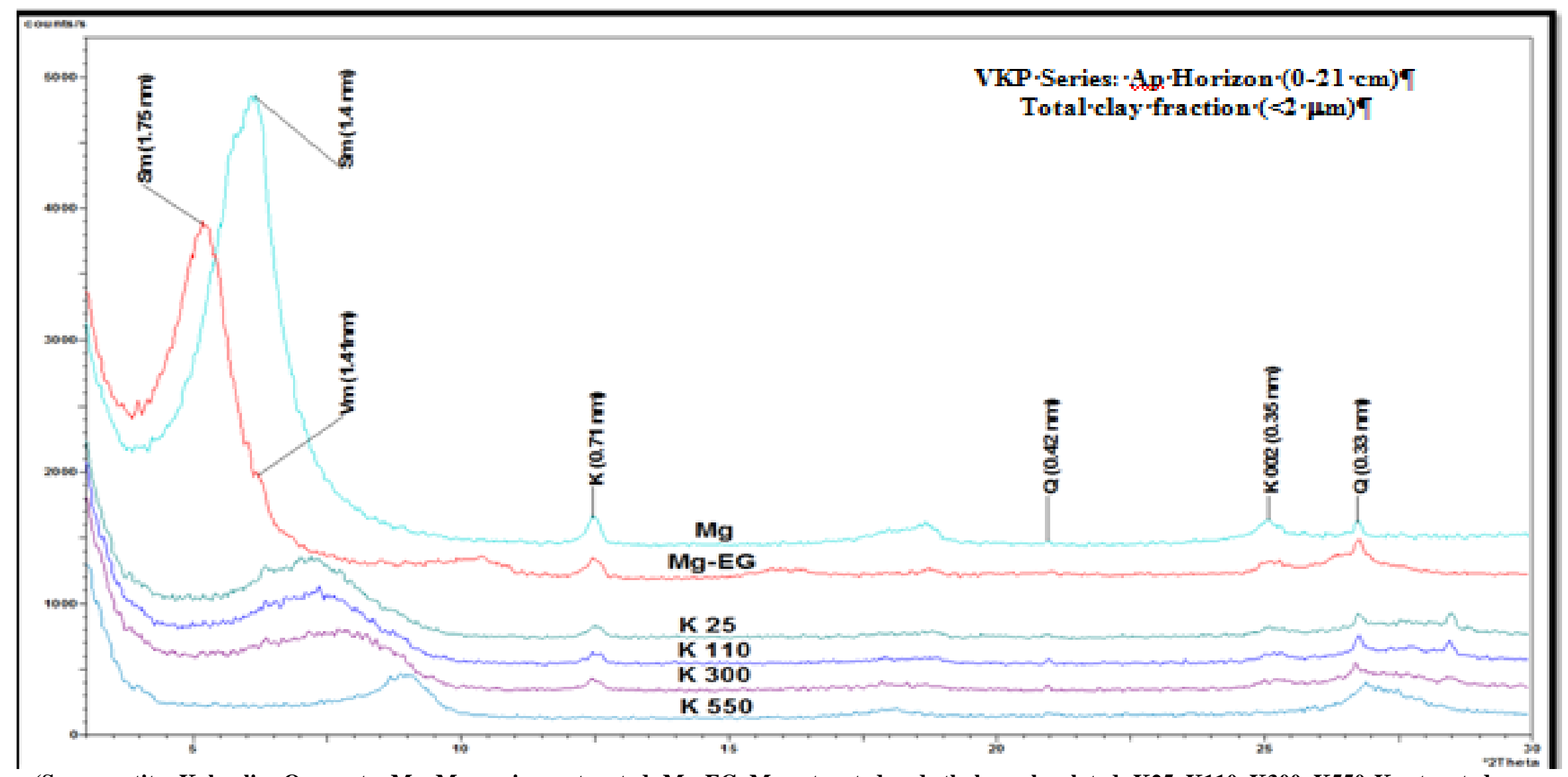

(Sm, smectite; K, kaolin; Q, quartz; Mg, Magnesium saturated; Mg-EG, Mg-saturated and ethylene glycolated; K25, K110, K300, K550-K saturated and heated at $25^{\circ}, 110^{\circ}, 300^{\circ}$ and $550^{\circ} \mathrm{C}$, respectively) 
Fig.11 X-ray diffractograms of clay fraction (VKP series, Bss horizon)

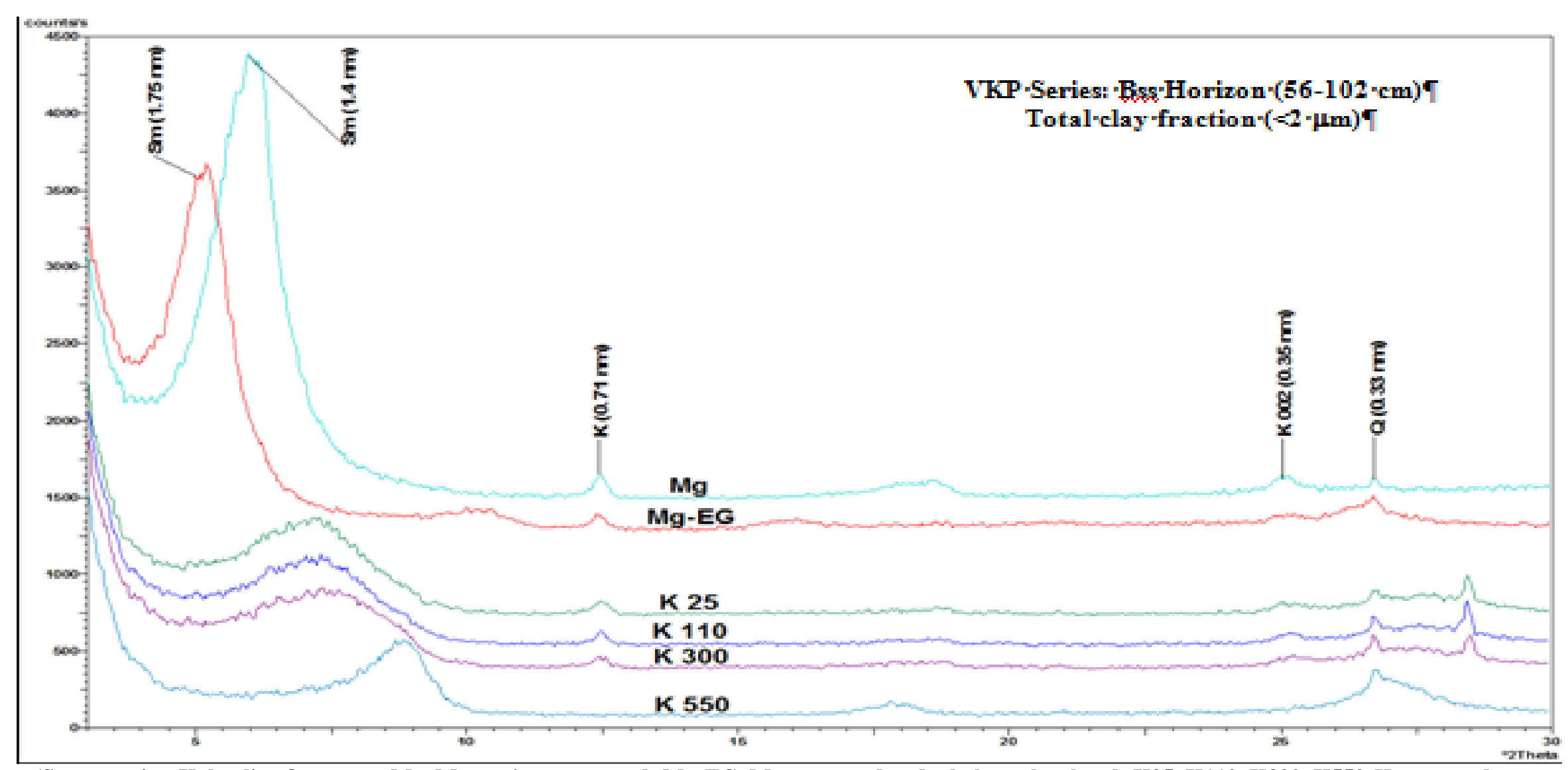

(Sm, smectite; K, kaolin; Q, quartz; Mg, Magnesium saturated; Mg-EG, Mg-saturated and ethylene glycolated; K25, K110, K300, K550-K saturated and heated at $25^{\circ}, 110^{\circ}, 300^{\circ}$ and $550^{\circ} \mathrm{C}$, respectively) 
Fig.12 X-ray diffractograms of clay fraction (NPT series, Ap horizon)

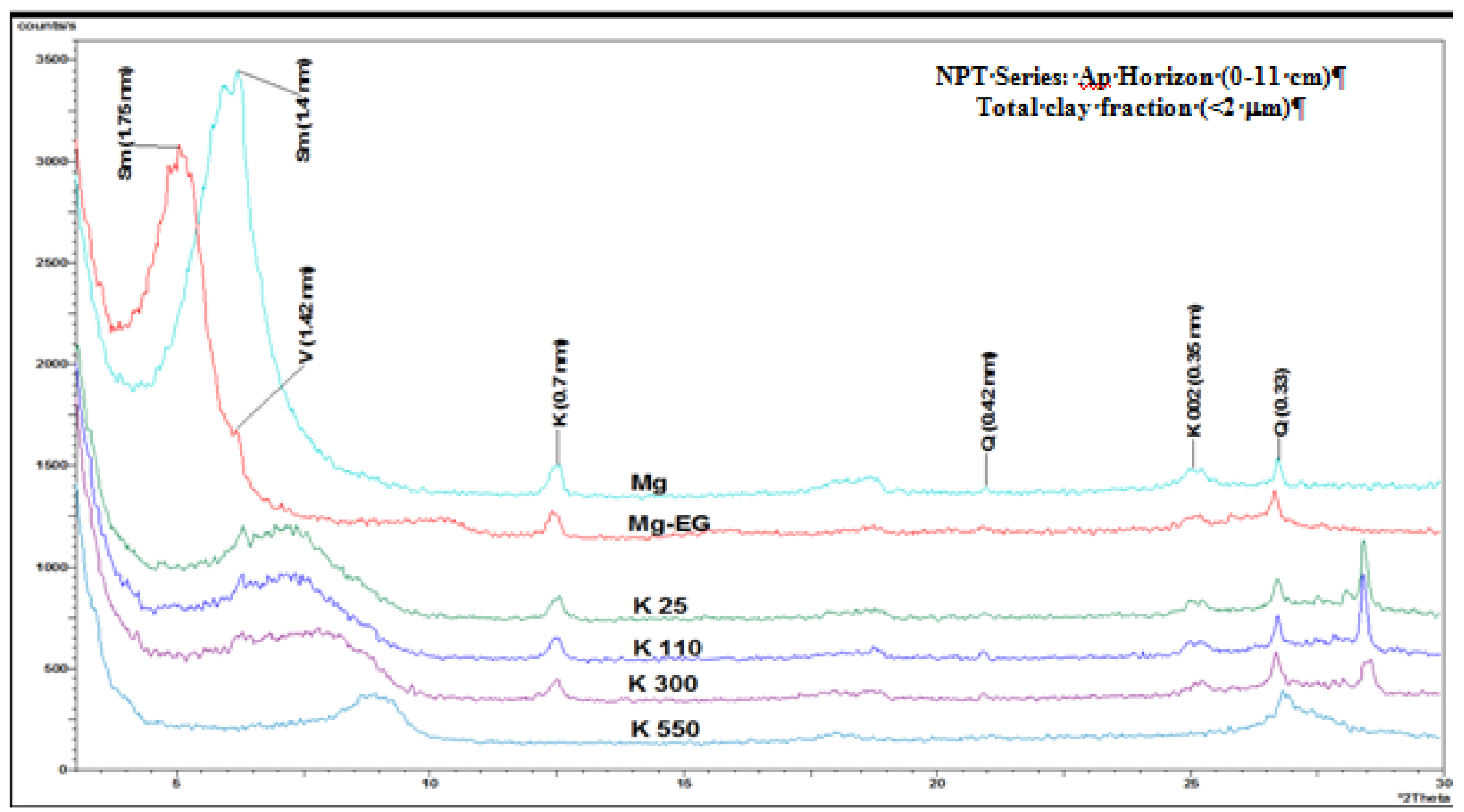

(Sm, smectite; K, kaolin; Q, quartz; Mg, Magnesium saturated; Mg-EG, Mg-saturated and ethylene glycolated; K25, K110, K300, K550-K saturated and heated at $25^{\circ}, 110^{\circ}, 300^{\circ}$ and $550^{\circ} \mathrm{C}$, respectively) 
Fig.13 X-ray diffractograms of clay fraction (NPT series, Bwk horizon)

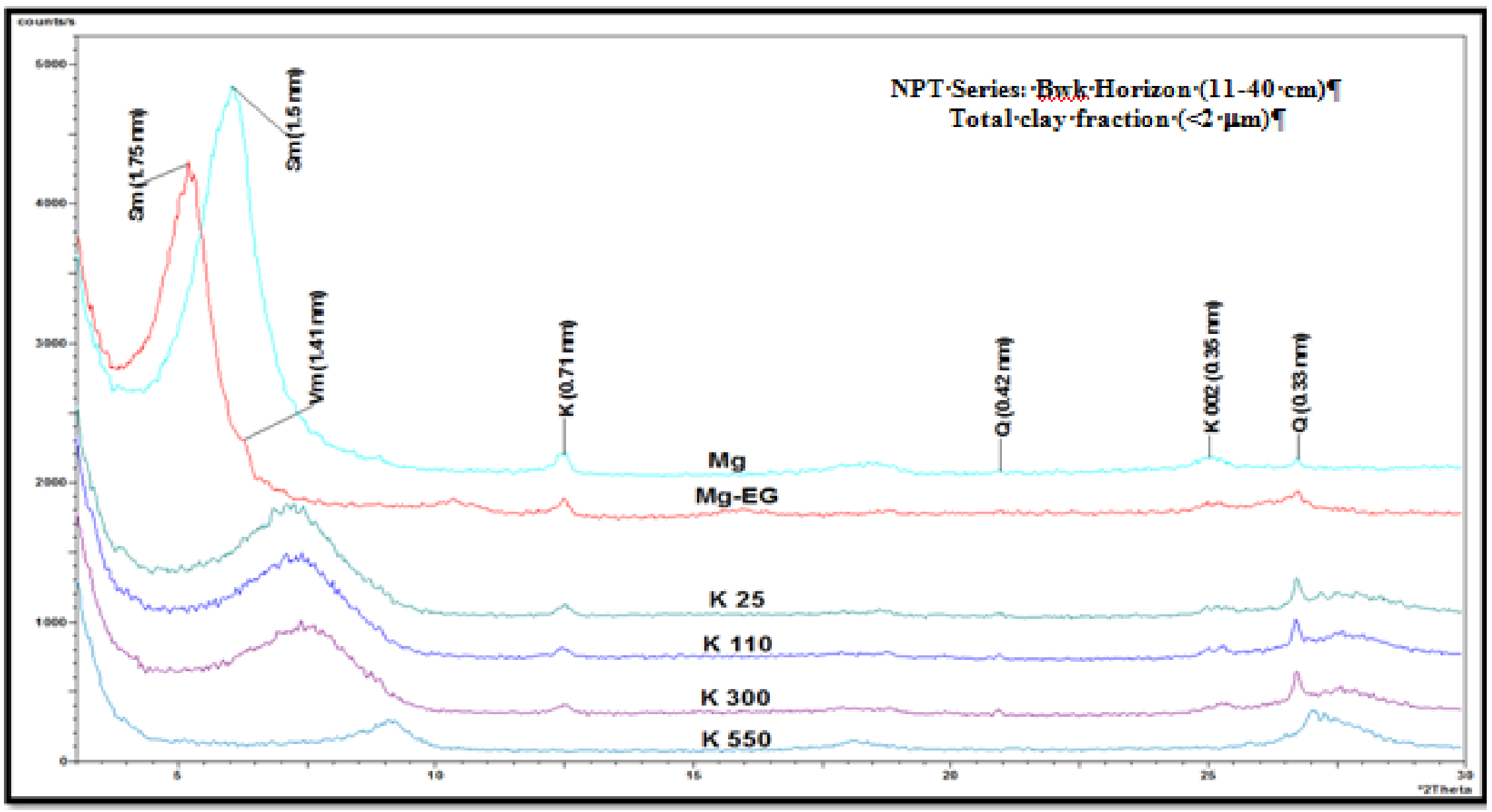

(Sm, smectite; K, kaolin; Q, quartz; Mg, Magnesium saturated; Mg-EG, Mg-saturated and ethylene glycolated; K25, K110, K300, K550-K saturated and heated at $25^{\circ}, 110^{\circ}, 300^{\circ}$ and $550^{\circ} \mathrm{C}$, respectively) 
Fig.14 X-ray diffractograms of clay fraction (HGK series, Ap horizon)

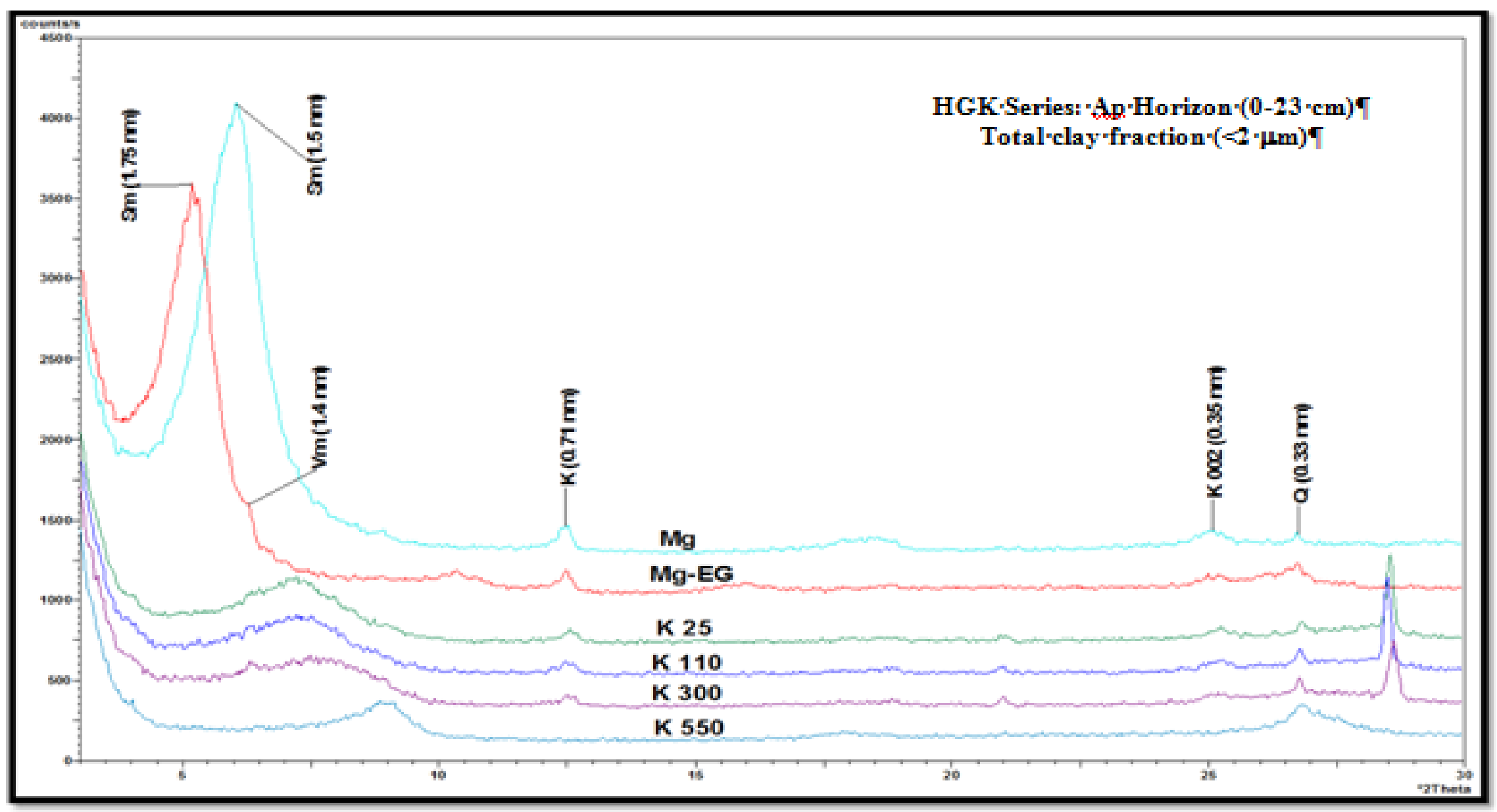

(Sm, smectite; K, kaolin; Q, quartz; Mg, Magnesium saturated; Mg-EG, Mg-saturated and ethylene glycolated; K25, K110, K300, K550-K saturated and heated at $25^{\circ}, 110^{\circ}, 300^{\circ}$ and $550^{\circ} \mathrm{C}$, respectively) 
Relative dominance of primary and secondary minerals in clay fractions

Secondary minerals, smectite dominated over vermiculite and kaoline in among the depth (Table 3). In case of MVD and NGT series in both the depths vermiculite was absent and smectitite dominated over kaolin.

The soils of Kanaginahala sub-watershed were brown to very dark grayish brown in colour with clay texture. The soils were slightly alkaline to alkaline in reaction and were nonsaline. The organic carbon content was low to medium. The soils had considerably higher exchangeable sodium percentage showed irregular trend with depth. The cation exchange capacity was high due to higher clay content.

The mineralogical composition of sand fraction of these soils was dominated by quartz followed by feldspar, olivines, biotite mica, pyroxenes, ferrihydrides and goethite. Mineralogy of clay showed relatively higher content of smectite than kaolin. The other mineral present was quartz. In most of the pedons, smectite content increased while kaolin and quartz content decreased with soil depth.

\section{Acknowledgement}

The authors are sincerely acknowledges Sujala-III Project GoK, Bangalore, for extending lab facilities to carry out the research and Head, Division of Soil Resource Studies, NBSS\&LUP, Nagpur for providing facilities during XRD analysis.

\section{References}

Bhattacharyya, T., Pal, D. K. and Deshpande, S. B., 1993, Genesis and transformation of minerals in the formation of red (Alfisols) and black
(Inceptisols and Vertisols) soils on Deccan basalt in the Western Ghats.J. Soil Sci., 44: 159-171.

Bhattacharyya, T., Pal, D. K. and Srivastava, P., 1999, Role of zeolites in persistence of high altitude ferruginous Alfisols of the humid tropical Western Ghats, India.Geoderma, 90(3\&4): 263276.

Black, C.A. 1965. Methods of Soil Analysis. AmSoc. Agro.Inc., Madison, Wisconsin, USA.

Deb, S. and Sahu, S. S., 2010, Study of mineralogy and weathering of two soil profiles of undulating plateau area of Jumarsubwatershed, Jharkhand, India. Int. J. Agric. Environ. Biotech.,3(3): 295-301.

Gjems, O. 1967.Studies on clay minerals andclay mineral formation in soil profiles in Scandinavia. Maddelser frodet Norske Skoforsoksvesen. 21: 303-415, Norway.

Jackson, M.L. 1979. Soil Chemical Analysis Advanced Coarse, 2nd edition, Published bythe author, University of Wisconsin, Madison, USA.

Jagadeesha, M. B., 2002, Clay mineralogy of some associated red and black soils of northern Karnataka. M. Sc.

(Agri.) Thesis, Univ. Agric. Sci., Dharwad, Karnataka (India).

Nagendra, B. R. and Patil, P. L., 2015, Characterization and classification of soil resources of Shirol West-1 microwatershed. Karnataka J. Agric. Sci., 28(4): 504-509.

Pal, D. K., Deshpande, S. B., Venugopal, K. R. and Kalbande, A. R., 1989, Formation of di- and tri-octahedral smectite as evidence for paleoclimatic changes in southern and central Peninsular India. Geoderma, 45(2): 175-184.

Ramamurthy, V., Naidu, L. G. K., Kumar, R., Srinivas, S. and Hegde, R., 2009, Soil 
based fertilizer recommendations for precision farming. Curr. Sci., 97(5): 641- 647

Sarma, V. A.K, Krishnan, P. and Budhial, S.C.1987.Laboratory Methods. Soil ResourceMapping of different states in India, NBSS Publ. 14, Nagpur.
Srivastava, P., Bhattacharyya, T. and Pal, D. K., 2002, Significance of the formation of calcium carbonates minerals in the pedogenesis and management of cracking clay soils (Vertisols) of India. Clays Clay Miner., 50: 111-126.

\section{How to cite this article:}

Madhusudhan and Patil, P. L. 2020. Studies on Sand and Clay Minerals of Kanaginahala SubWatershed in Gadag District, Karnataka. Int.J.Curr.Microbiol.App.Sci. 9(01): 386-405. doi: https://doi.org/10.20546/ijcmas.2020.901.043 